\title{
Discutindo a Cultura na Prática Médica: Relato de Experiência em um Centro Universitário de São Paulo
}

\author{
Manso, Maria Elisa Gonzalez \\ Centro Universitário São Camilo - mansomeg@hotmail.com
}

Introdução: a Antropologia da Saúde busca ampliar a visão que as áreas técnicas têm sobre o processo de adoecimento, na tentativa de superar o paradigma da fragmentação e hiperespecialização. o entendimento da influência da cultura, tanto na inserção em uma equipe de trabalho quanto na relação médico-paciente, propicia ao futuro médico um olhar crítico sobre a atual prática clínica tendo como pressupostos a humanização e a integralidade da atenção. Este foi o propósito do oferecimento do curso Cultura e Prática Clínica. Metodologia: Trata-se do relato da experiência de dois anos de trabalho com o citado curso, desenvolvido em um centro universitário privado localizado na cidade de São Paulo e voltado para discentes da faculdade de medicina que cursam do primeiro ao sétimo semestres. o curso é baseado na problematização de casos clínicos vivenciados pelos alunos, buscando a influência dos aspectos culturais e as dificuldades trazidas pela forma como o ensino médico ainda se pauta no que tange à hiperespecialização e à visão fragmentada do ser humano em contraste com os princípios do SUS e a proposta de humanização da atenção. Resultados: os temas de maior recorrência discutidos ao longo destes dois anos referem-se aos conflitos entre as diferentes concepções que o médico e o enfermo têm do adoecer, do itinerário terapêutico e da adesão ao tratamento, bem como da visão que os discentes trazem de seu papel enquanto profissional de saúde. Alguns outros tópicos frequentes incluem: a visão atual sobre as dimensões do corpo humano e seus reflexos na imagem corporal; as diferenças de gênero e etnias frente aos procedimentos médicos, tanto preventivos quanto curativos; questões culturais que permeiam o cuidado familiar e espiritualidade, entre outros. a participação discente tem sido crescente e alguns dos alunos egressos continuam trabalhando com os temas que problematizaram. Discussão: a dificuldade encontrada ao longo destes dois anos é o conflito entre a proposta do curso e a visão que o aluno traz do que é ser médico. por uma característica própria da instituição, a maioria dos graduandos advém de famílias de médicos e já trazem uma construção cultural da prática clínica pautada na assimetria de poder médico-paciente e com ênfase na hiperespecialização. Outra dificuldade é o horário de realização do curso, o qual, por ser disciplina eletiva, não compõe a grade e é realizado à noite. Esta dificuldade também tem se mostrado como uma oportunidade, pois o aluno escolhe o curso com base em sua proposta e na experiência dos egressos. Conclusão: Apesar das dificuldades de incorporar uma visão diferenciada da prática clínica, este curso vem trazendo melhorias não só na atenção à saúde dos adoecidos, mas, aos próprios discentes participantes, principalmente de semestres mais avançados, alguns dos quais têm repensado suas escolhas e se colocado de uma forma mais aberta perante o sistema de saúde brasileiro e suas necessidades.

Manso, Maria Elisa Gonzalez. Discutindo a Cultura na Prática Médica: Relato de Experiência em um Centro Universitário de São Paulo. In: Anais do Congresso Internacional de Humanidades \& Humanização em Saúde [= Blucher Medical Proceedings, num.2, vol.1]. São Paulo: Editora Blucher, 2014. ISSN 2357-7282 DOI 10.5151/medpro-cihhs-10519 